\title{
Part of Teachers and Parents in Children's Education
}

\author{
Muhammad Yasir Imam ${ }^{1}$ \\ UG Student, Dept. of CS and IT \\ Al-hamd Islamic University \\ Bhara Khau, Islamabad, Pakistan \\ researcherimam@gmail.com \\ Asima Saleem ${ }^{4}$ \\ Dept. of Management Sciences \\ NUML University \\ Islamabad, Pakistan \\ asimas009@gmail.com
}

\author{
Nabila Jannat ${ }^{2}$ \\ Lecturer, Dept. of CS and IT \\ Al-hamd Islamic University \\ Bhara Khau, Islamabad, Pakistan \\ nabila.jannat@alhamd.pk
}

\author{
Gul Sher Khan ${ }^{3}$ \\ Dept. of Management Sciences \\ GC University \\ Faisalabad, Pakistan \\ Khan27135110@gmail.com \\ Saman Fatima ${ }^{5}$ \\ UG Student, Dept. of CS and IT \\ Al-hamd Islamic University \\ Bhara Khau, Islamabad, Pakistan \\ Samanfatima.se@gmail.com
}

\begin{abstract}
In this paper, our study focuses on the role of teachers and parents in children's education. Parents are the first teachers of a child. They influence their children to a greater extent and play a major role in inculcating values of education in them. The second major role in children's education done by a teacher. A teacher also plays a very important role in children's education as a nation builder. Unfortunately, due to the advancements in technology and busy life schedules, parents and teachers have not been able to inculcate the true educational values in children. There is a number of factors which are responsible for this problem. This study provides information about how parents and teachers play their role and what are their perceptions are in this regard. Here, elementary school teachers and children have been targeted. Data is collected by personal visits and were analyzed using SPSS. Data type is consist of questionnaires. In this paper, we also used two frameworks, theoretical, conceptual framework, and also use t-test which is used to determine the significant differences between the means of two groups. Both the teachers and parents said that there should be strong coordination between them for helping their children to perform better at schools.
\end{abstract}

Keywords: Education, Parents, Teachers, Children's education

\section{INTRODUCTION}

It is difficult to imagine a teacher or school leader who is unaware of the importance of teaching highdiscipline thinking skills to prepare young men and women for life in the 21 st century. However, the extent to which higher-order thinking skills are taught and assessed has become an area of debate, with many teachers and employers expressing concern that the young people 'Can't think'. When we talk about 'higher-order thinking', what are we talking about? Brockhart (2010) identifies the definition of superior discipline thinking in three categories. (1) Those who define high discipline thinking in terms of migration, (2) those who explain it in critical thinking, (3) People who explain it in terms of solving a problem. In the Transition category, Anderson, Kreuthal et al (2001) explain how the transition is different from maintaining: two very important educational goals are to promote and promote the transition (which occurs at present). , Indicates meaningful education)... Retention requires that students remember what they have learned, while transfer requires not only the students to remember but also to realize and understand what they have learned to be able to use. While learning requires thinking in learning, higherorder thinking is in the "transition". That is students not only gain knowledge and skills but can apply them to new situations as well. According to Brockert (2010), this is the kind of thinking that applies to outof-school life where thinking is made up of a series of assigned assignments, rather than "a series of transition opportunities". The category of critical thinking includes definitions that include 'reasonable, reflective thinking', deciding what to believe or what to do (Norris \& Ennis, 1989) and 'artistic thinking', which includes reasoning. Includes inquiries and inquiries, observations and statements. Comparing and adding, finding complexity, and finding perspectives (Berhal, 2008). In critical thinking, being 
"thinkable" means that students can apply intelligent judgment or offer reasonable criticism. After that, the purpose of teaching is to teach students that they need to be wise in how to make the right decisions and use the right decisions. The skills this student needs to teach include; the ability to test the credibility of a source. Identify assumptions, common and prejudice; identify concepts in the use of language; understand the purpose of written or spoken text; identify the audience; and compare different strategies used to accomplish the purpose of the text. Make important decisions about performance. In the category of problem-solving, Brockhort offers the following definitions: The student faces a problem when the student wants to reach a particular conclusion or purpose, but the appropriate method or solution to use is to reach it. Is. Not automatically recognized. The problem to be solved is how to reach the desired goal. Since a student cannot automatically identify the way to reach the desired goal, he or she should use one or more thinking processes. These thinking processes are called problem-solving (Nitko \& Brockhardt, 2007). These can include remembering information, learning with understanding, criticizing ideas, devising creative alternatives, and communicating effectively. The broad definition of problem-solving is that it is a skill that enables humans to find solutions to a problem that cannot be solved simply by memorizing (ibid). Although there are many closed problems, for example in mathematics in which students often have to use memory to practice particular algorithms, many problems are quite common and solved by memory alone. Can't be done. - Or they may have more than one solution. Or it could be a real problem where the answer is not yet known. As conditions change, problems can change. For example, staying in a budget is an open issue. Burnsford and Stein (1984) point out that problem-solving is the common methodology behind all thinking, including memory, critical thinking, creative thinking, and effective communication. He emphasizes that in order to remember something, students have to identify it as a problem ("I need to memorize a list of planets, a poem, a capital city. How do I do that?). Can I? "?") And devise a solution that works. Likewise, critical thinking is a matter of problem-solving - how well does Shakespeare develop this character? Difficulty in communication and communication. Involves solving? Who is my audience? How can I communicate with them? What words can I use to explain? Project Zero, developed at Harvard University, provides an example of how teachers can help students think through arts, and the 'Artful thinking palette' (Berhal, 2008). Use. Students were asked to use six thought-provoking ideas for viewing art: searching, discussing, questioning and examining perspectives, observing and describing, comparing and adding, and finding complexity. To do - Teaching students this thinking skill is useful not only in the arts but in other disciplines as well as preparing for standardized tests like the Queensland Core Skills Test. Brockhardt (2010) argues that if teachers think of higher discipline as a solution to a problem, they should use it as a lesson to teach students how to identify and resolve problems in school and in life. Can set goals. - It says that it involves not only solving problems solved by teachers, but also solving new problems that 'define themselves, and create something new as a solution'.

\section{LITERATURE REVIEW}

Parents are the child's first role model. Children behave, react and imitate the same as their parents. Parents play an important role in encouraging and motivating their kids to learn. Good parental support helps a child to be a positive, healthy and good life long learner. Children acquire skills at the very early stage of their life if the parents are responsive and understanding. It is important for families to fulfill their responsibilities regarding their children's physical care (Honig, 2002) and their safety and health in terms of their development (Tinsley et al., 2002). Apart from this, families have responsibilities related to school and education. Hornby (2000) listed the responsibilities that teachers wanted parents to fulfill. These are; making an effort to the individual necessities and health problems of their children, helping their lessons and homework at home, participating in school activities, reading the reports and letters sent to them and getting in touch with the teacher, encouraging their children to participate in school activities, participating in the parent's meetings and communicating with the teacher when necessary both at school and out of school, and giving the teacher their home and work addresses and telephone numbers. These are the responsibilities that parents must fulfill regarding the school and education (Kiral, 2019). 
Likewise, major challenges for teachers are to nurture children's learning and give him various experiences to face this challenging world. S/he molds the child to be a responsible and independent learner. A teacher is the first person from whom a child learns his social skills in school. Teachers make him comfortable and guide him with the early concepts and developmental skills of life. Open-minded, well balanced and a planned teacher has a great power to bring a positive change in the child's development. As the child grows and develops mastery in different skills, the teacher becomes a real guide in nurturing his interest and learning to make him more independent. Radically changing the learning environment can affect teachers' identities and their approaches to teaching in predictable ways that can inform teacher education and professional development programs for STEM teachers, maximizing the success of teachers as they implement student-centered pedagogy (Keiler, 2018). Many teachers also spend time researching various questions of educational effectiveness that expand the understanding of the dynamics of learning. And more teachers are spending time mentoring new members of their profession, making sure that education school graduates are truly ready for the complex challenges of today's classrooms (Lanier, 1997).

\section{Objectives of the study}

1. Investigate teachers' ideas and measures on how to interact with parents of their students.

2. Interact with parents of their students to understand the purpose of the teachers.

3. Finding ways for teachers to interact with parents.

\section{Research Questions}

The following are some of the major questions which were examined in this research study:

1. What are teachers' and the parent's attitudes about education?

2. In what ways do parents and the teachers affect their children's learning?

3. What barriers do teachers and the parents cite as a possible detriment in their children's education?

4. What is the effect of teacher attitudes on the student's learning?

5. What is the effect of the parent's attitudes in the children's learning?
6. Is there a relationship between teachers 'thoughts and actions on how to interact with their student's parents?

7. What are the goals of parenting to interact with parents?

8. How do teachers adapt to interact with their students' parents?

9. What problems do teachers face in creating a positive interaction with parents?

10. Is there a difference between the perceptions of private versus private school teachers about the purpose of interacting with parents?

\section{METHODOLOGY}

The purpose of this study was to examine the role of parents and teachers' practices regarding their children's education. By exploring the attitudes and roles of parents and teachers, it was studied whether there's a significant effect on the involvement of both. Some $50 \%$ of teachers and $50 \%$ of parents were approached and their responses were recorded. Also, an equal weightage was given to the teachers from both private and public schools and parents accordingly.

\section{Theoretical Framework}

This study was based on the principles included in Daniel Stuffblum's CIPP model (1983). Context Input, Process, and Product (CIPP) model is an open system comprehensive model to guide the organizational and auditory evaluation of a program, and the effectiveness of this program for decision-making and decision-making. Provides. This includes the Context, Input, Process, and Product (CIPP). These types are generally seen as a separate form of evaluation, but they can also be seen as a step or step in a comprehensive diagnosis. This study process includes teachers 'and students' thinking, feelings, attitudes, and actions within the classroom or learning situation, as well as the interaction patterns and the details of the learning environment that result from these interactions. Product testing identifies desired and unintended and short-term and long-term results. The products of this study include a specific learning measure or measure of student achievement, social skills and understanding development.

This research was led by Daniel Stufflebaum's CIPP model, which explores student learning achievements as a result of environmental or situational factors (perspectives), teachers' and student characteristics (input), and classroom interaction. Or changes in 
behavior (products). This is how the concept can be conceived.

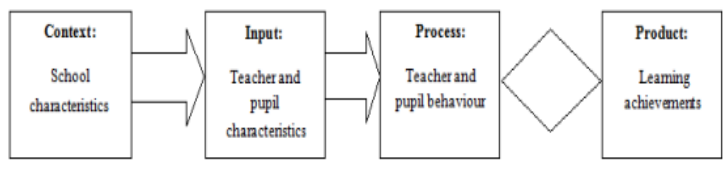

\section{Figure 1. Principles of CIPP Model}

This model refers to the input and output as the beginning and end of the learning process in a particular context. This study attempts to evaluate the application of learning domains of primary school teachers in this regard, classroom education in the primary schools of Pakistan.

\section{Conceptual Framework}

The theoretical framework suggests a synergy between learning domains and classroom instruction.

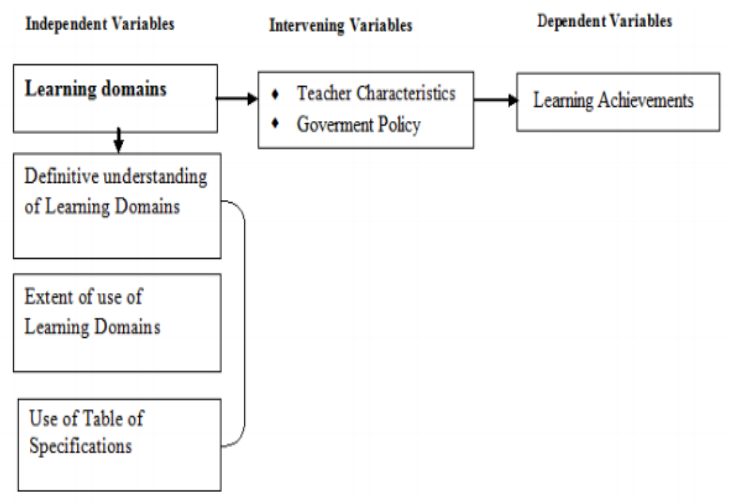

Figure 2: The Conceptual Framework

Through various classroom practices, teachers play a significant role in the classroom process, which relies heavily on their teaching abilities. The process outlined in Figure 2 illustrates that learning domains that are independent variables influence learning success.

\section{T-test}

The $t$-test is one type of inferential statistics. It is used to determine whether there is a significant difference between the means of two groups. With all inferential statistics, we assume the dependent variable fits a normal distribution. When we assume a normal distribution exists, we can identify the probability of a particular outcome. We specify the level of probability (alpha level, level of significance, $p$ ) we are willing to accept before we collect data $(p<.05$ is a common value that is used).

After we collect data we calculate a test statistic with a formula. We compare our test statistic with a critical value found on a table to see if our results fall within the acceptable level of probability. Modern computer programs calculate the test statistic for us and also provide the exact probability of obtaining that test statistic with the number of subjects we have.

\section{Method of study}

The subject of the study was specific through the nature and method of the survey descriptive research was undertaken to complete this study. The study was restricted to the initial level in the Punjab province of Pakistan. The study population was composed of elementary level school teachers.

A sample of 700 elementary-level teachers was selected using the multistage sampling method. The sample selection method includes a random sampling of 7 districts, 20 schools from each district $(20 \times 7=$ 140) by sampling convenience and randomly sampling five teachers $(140 \times 5=700)$ from current elementary school teachers in selected schools. By the study tool was a self-generated questionnaire consisting of 30 items, initially containing three demographic information items. The pilot was tested on a sample of 50 teachers after evaluating the validity of its contents by expert opinion methodology. Its reliability was determined by Cronbach's alpha value, which was 0.914 . Data collected by personal visits. Only 640 teachers returned the questionnaire. Data were analyzed using SPSS, averaging average scores, correlations, and t-test data.

\section{Outcomes of the study}

\section{Relationship between Parental Involvement Ideas and Practices}

Table 1 identifies the relationships between teachers 'views and practices regarding their efforts to foster teachers' parent interactions. According to the data, the value of the pairing pattern correlation $(\mathrm{r}=0.526, \mathrm{p}=$ 0.000) indicates a strong relationship between teachers' thoughts and attitudes (perceptions $=22.78$, methods $=22.623, p=0.000$ ). The results of the $\mathrm{t}$-test $(\mathrm{t}=1.14, \mathrm{P}=0.25)$ also showed a slight difference 
between the groups. This shows that teachers work according to their ideas. There is no contradiction between the views of the teachers and the actions of the teachers.

Table 1: Relationships between Perceptions and Procedures for parents interactions $(n=640)$

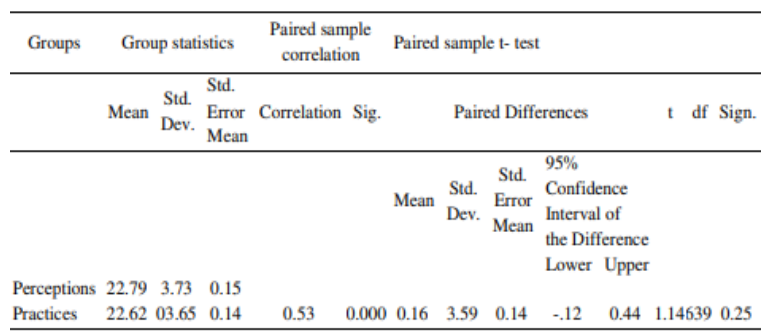

\section{Objectives of teachers who interact with parents}

Table 2 shows the results of teachers' goals of interacting with parents of their students. According to the data provided by teachers on a three-point scale (1 $=$ not agree, $2=$ slightly agree, $3=$ strongly agree), the average score value of all aspects indicated in the table is above 2.00. This shows that teachers try to interact with parents to discuss student issues and to guide them on ways to improve their children's education. They want to explain the importance of completing homework and instruct parents to supervise their children in connection with the homework assignments. They monitor students' attendance at school and realize that their interaction with parents helps them reduce dropout ratios and improve student attendance ratios. Therefore, teachers' interaction with parents builds trust among students, opens up better education opportunities and ultimately contributes to the effectiveness of teacher education in school.

Analysis of multiple groups' comparisons through independent sample test statistics for different types of schools indicates that, although the group scores of private school teachers are lower than the scores of public teachers, in all aspects of education. There is a slight difference between the groups in terms of goals. These discoveries show that teachers are concerned about the need to interact with parents who are working in public schools or in private schools.
Table 2: The purpose of school teachers is to create reciprocal relationships with parents $(\mathrm{n}=640)$

\begin{tabular}{|c|c|c|c|c|c|c|c|c|c|c|c|c|}
\hline \multirow{4}{*}{$\begin{array}{l}\text { Sr. } \\
\text { no. } \\
\end{array}$} & \multirow[t]{4}{*}{ Content } & \multicolumn{5}{|c|}{ Group Statistics } & \multicolumn{6}{|c|}{ Independent sample t- test (df=638) } \\
\hline & & \multirow{3}{*}{$\begin{array}{c}\text { School } \\
\text { type }\end{array}$} & \multirow{3}{*}{\multicolumn{2}{|c|}{ Mean }} & \multirow{3}{*}{ SD } & \multirow{3}{*}{$\begin{array}{l}\text { Std. } \\
\text { Eror } \\
\text { Mean }\end{array}$} & \multirow{3}{*}{$\begin{array}{c}\text { t. } \\
\text { score }\end{array}$} & \multirow{3}{*}{$\begin{array}{l}\text { Sig. } \\
\text { (2- } \\
\text { tailed) }\end{array}$} & \multirow{3}{*}{$\begin{array}{l}\text { Mean } \\
\text { Differ } \\
\text { ence }\end{array}$} & \multirow{3}{*}{$\begin{array}{c}\text { Std. } \\
\text { Emor } \\
\text { Differ } \\
\text { ence } \\
\end{array}$} & \multirow{2}{*}{\multicolumn{2}{|c|}{$\begin{array}{c}95 \% \\
\text { Confidence } \\
\text { Interval of the } \\
\text { Difference }\end{array}$}} \\
\hline & & & & & & & & & & & & \\
\hline & & & & & & & & & & & Lower & Upper \\
\hline \multirow[t]{2}{*}{$T$} & $\begin{array}{l}\text { Increase teacher } \\
\text { effectiveness in }\end{array}$ & Public & 2.677 & 2.665 & .666 & .036 & .473 & .636 & .025 & .053 & -.079 & .129 \\
\hline & $\begin{array}{l}\text { educational } \\
\text { process. }\end{array}$ & Private & 2.652 & & .678 & .039 & & & & & & \\
\hline \multirow[t]{2}{*}{2} & $\begin{array}{l}\text { Improve } \\
\text { educational }\end{array}$ & Public & 2.653 & 2.656 & .631 & .034 & -.101 & .920 & -.005 & 050 & -.104 & .093 \\
\hline & $\begin{array}{l}\text { attainment of } \\
\text { students. }\end{array}$ & Private & 2.658 & & .641 & .036 & & & & & & \\
\hline \multirow[t]{2}{*}{3} & Enhance higher & Public & 2.594 & 2.576 & .704 & .038 & .674 & .501 & .038 & .056 & -.073 & .150 \\
\hline & $\begin{array}{l}\text { rates of homework } \\
\text { completion. }\end{array}$ & Private & 2.556 & & .734 & .042 & & & & & & \\
\hline \multirow[t]{2}{*}{4} & Enhance student & Public & 2.591 & 2.578 & .679 & .036 & .522 & .602 & .029 & .055 & -.079 & .137 \\
\hline & $\begin{array}{l}\text { motivation for } \\
\text { study. }\end{array}$ & Private & 2.562 & & .715 & .041 & & & & & & \\
\hline \multirow[t]{2}{*}{5} & Reduce dropout & Public & 2.615 & 2.581 & .662 & .030 & 1.339 & .181 & .072 & .054 & -.033 & .178 \\
\hline & rate & Private & 2.543 & & .703 & .040 & & & & & & \\
\hline \multirow[t]{2}{*}{6} & Develop positive & Public & 2.568 & 2.561 & .703 & .038 & .271 & .786 & .015 & .055 & -.093 & .124 \\
\hline & $\begin{array}{l}\text { interaction with } \\
\text { parents }\end{array}$ & Private & 2.553 & & .698 & .040 & & & & & & \\
\hline \multirow[t]{2}{*}{7} & Enhance & Public & 2.503 & 2.494 & .735 & .040 & .335 & .738 & .020 & .058 & -.094 & .134 \\
\hline & socialization & Private & 2.483 & & .736 & .042 & & & & & & \\
\hline \multirow[t]{2}{*}{8} & Improve & Public & 2.576 & 2.550 & .663 & .036 & 1.041 & .298 & . 057 & .05483 & -.050 & .164 \\
\hline & $\begin{array}{l}\text { educational } \\
\text { opportunities for } \\
\text { children. }\end{array}$ & Private & 2.519 & & .723 & .041 & & & & & & \\
\hline \multirow[t]{2}{*}{9} & $\begin{array}{l}\text { Communicate } \\
\text { students' }\end{array}$ & Public & 2.544 & 2.516 & .697 & .037 & 1.071 & .284 & .060 & .05688 & -.050 & .172 \\
\hline & $\begin{array}{l}\text { problems to } \\
\text { parents. }\end{array}$ & Private & 2.483 & & .741 & .042 & & & & & & \\
\hline \multirow[t]{2}{*}{10} & $\begin{array}{l}\text { Develop } \\
\text { confidence in }\end{array}$ & Public & 2.544 & 2.502 & .688 & .037 & 1.577 & .115 & .090 & .05752 & -.022 & .203 \\
\hline & $\begin{array}{l}\text { children to do } \\
\text { things in better }\end{array}$ & Private & 2.453 & & .766 & .044 & & & & & & \\
\hline \multirow[t]{2}{*}{11} & Develop the & Public & 2.559 & 2.536 & .700 & .038 & .853 & .394 & .049 & .05770 & -.064 & .162 \\
\hline & $\begin{array}{l}\text { personality of } \\
\text { children. }\end{array}$ & Private & 2.509 & & .759 & .043 & .849 & & & & & \\
\hline \multirow[t]{2}{*}{12} & Guide parents to & Public & 2.585 & 2.552 & .684 & .037 & 1.299 & .194 & .072 & .05585 & -.037 & .182 \\
\hline & support their child & Private & 2.513 & & .727 & .041 & 1.295 & & & & & \\
\hline \multirow[t]{2}{*}{13} & Improve students' & Public & 2.585 & 2.553 & .701 & .038 & 1.195 & .232 & .069 & .05793 & -.044 & .182 \\
\hline & $\begin{array}{l}\text { attendance ratio at } \\
\text { school. }\end{array}$ & Private & 2.516 & & .763 & .043 & 1.190 & & & & & \\
\hline \multirow[t]{2}{*}{14} & Aware parents & Public & 2.559 & 2.574 & .712 & .038 & -.546 & .586 & -.030 & .05541 & -.139 & .078 \\
\hline & $\begin{array}{l}\text { weaknesses of } \\
\text { child in studies. }\end{array}$ & Private & 2.589 & & .684 & .039 & -.547 & & & & & \\
\hline
\end{tabular}

\section{Ways to communicate with parents through teachers}

Table 3 shows the techniques for parent interaction. The score for all aspects of the indicators in the table is above 2.00 according to statistics. This suggests that teachers use a variety of methods to communicate with parents. They use diaries and electronic mail to communicate messages, students' progress, and parents. Organize parent-teacher general meetings and special meetings with parents in specific situations in the school and discuss student progress and ways to improve student development and problems. They sent notices to parents about poor development and discipline in the school. Above all, Teachers value parenting during co-curricular activities arrangements. They invite them to showcase their progress in activities other than study. All of these help teachers build relationships with parents and share ways to improve children from an educational as well as developmental perspective. T-test results show a slight 
difference between the groups with respect to all aspects shown in the table. This suggests that teachers in private and public schools adopt similar approaches to interacting with parents and engaging them in the children's educational process.

Table 3: Techniques for interacting with parents of school teachers $(n=640)$

\begin{tabular}{|c|c|c|c|c|c|c|c|c|c|c|c|c|}
\hline \multirow[t]{3}{*}{$\begin{array}{l}\text { Sr. } \\
\text { no }\end{array}$} & \multirow[t]{3}{*}{ Content } & \multicolumn{5}{|c|}{ Group Statistics } & \multicolumn{6}{|c|}{ Independent sample t-test ( $\mathrm{df}=638$ ) } \\
\hline & & $\begin{array}{l}\text { School } \\
\text { type }\end{array}$ & & lean & $\begin{array}{c}\text { Std. } \\
\text { Deviati } \\
\text { on }\end{array}$ & $\begin{array}{l}\text { Std. } \\
\text { Error } \\
\text { Mean }\end{array}$ & $\begin{array}{c}\text { t. } \\
\text { score }\end{array}$ & $\begin{array}{l}\text { Sig. } \\
(2- \\
\text { tailed })\end{array}$ & $\begin{array}{l}\text { Mean } \\
\text { Differ } \\
\text { ence }\end{array}$ & $\begin{array}{l}\text { Std. } \\
\text { Error } \\
\text { Differ } \\
\text { ence }\end{array}$ & $\begin{array}{r}95^{\circ} \\
\text { Confid } \\
\text { Interval } \\
\text { Differe }\end{array}$ & $\begin{array}{l}\text { \% } \\
\text { dence } \\
\text { lof the } \\
\text { ence }\end{array}$ \\
\hline & & & & & & & & & & & Lower 1 & Upper \\
\hline 1 & $\begin{array}{l}\text { Use diary to } \\
\text { communicate }\end{array}$ & $\begin{array}{l}\text { Public } \\
\text { Private }\end{array}$ & $\begin{array}{l}2571 \\
2.473\end{array}$ & 2.525 & $\begin{array}{l}.690 \\
.745\end{array}$ & $\begin{array}{l}.037 \\
.042\end{array}$ & 1.717 & .086 & .097 & .056 & -.014 & .209 \\
\hline 2 & $\begin{array}{l}\text { Sent e-mail to report } \\
\text { progress/problems of } \\
\text { children to parents. }\end{array}$ & $\begin{array}{l}\text { Public } \\
\text { Private }\end{array}$ & $\begin{array}{l}2.443 \\
2.493\end{array}$ & 2.467 & $\begin{array}{l}.769 \\
.732\end{array}$ & $\begin{array}{l}.041 \\
.042\end{array}$ & -.833 & .405 & -.049 & .059 & -.166 & .067 \\
\hline 3 & $\begin{array}{l}\text { Parent-teacher } \\
\text { meetings }\end{array}$ & $\begin{array}{l}\text { Public } \\
\text { Private }\end{array}$ & $\begin{array}{l}2.618 \\
2576\end{array}$ & 2.598 & $\begin{array}{l}.666 \\
.695\end{array}$ & $\begin{array}{l}.036 \\
.040\end{array}$ & .783 & .434 & .042 & .053 & -.063 & .148 \\
\hline 4 & $\begin{array}{l}\text { Call parents in special } \\
\text { meetings }\end{array}$ & $\begin{array}{l}\text { Public } \\
\text { Private }\end{array}$ & $\begin{array}{l}2.452 \\
2516\end{array}$ & 2.482 & $\begin{array}{l}.754 \\
.736\end{array}$ & $\begin{array}{l}.041 \\
.042\end{array}$ & -1.082 & .280 & -063 & 059 & -.179 & .052 \\
\hline 5 & $\begin{array}{l}\text { Discuss students' } \\
\text { strengghs and } \\
\text { weaknesses during } \\
\text { parent-teacher } \\
\text { meetings }\end{array}$ & $\begin{array}{l}\text { Public } \\
\text { Private }\end{array}$ & $\begin{array}{l}2594 \\
2509\end{array}$ & 2.554 & $\begin{array}{l}.687 \\
.714\end{array}$ & $\begin{array}{l}.037 \\
.041\end{array}$ & 1.528 & .127 & .084 & 055 & -.024 & .193 \\
\hline 6 & $\begin{array}{l}\text { Sent notices to parents } \\
\text { regarding } \\
\text { problems/issues related } \\
\text { to children's } \\
\text { education. }\end{array}$ & $\begin{array}{l}\text { Public } \\
\text { Private }\end{array}$ & $\begin{array}{l}2.520 \\
2.450\end{array}$ & 2.487 & $\begin{array}{l}.731 \\
.774\end{array}$ & $\begin{array}{l}.039 \\
.044\end{array}$ & 1.181 & .238 & .070 & .059 & -046 & .187 \\
\hline 7 & $\begin{array}{l}\text { Sent performance } \\
\text { report to parents on } \\
\text { monthly basis. }\end{array}$ & $\begin{array}{l}\text { Public } \\
\text { Private }\end{array}$ & $\begin{array}{l}2.535 \\
2.496\end{array}$ & 2.517 & $\begin{array}{l}.722 \\
.718\end{array}$ & $\begin{array}{l}.039 \\
.041\end{array}$ & .680 & .497 & .038 & 057 & -.073 & .150 \\
\hline 8 & $\begin{array}{l}\text { Invite parents in co } \\
\text { curricular activities }\end{array}$ & $\begin{array}{l}\text { Public } \\
\text { Private }\end{array}$ & $\begin{array}{l}2.485 \\
2.427\end{array}$ & 2.457 & $\begin{array}{l}.715 \\
.794\end{array}$ & $\begin{array}{l}.038 \\
.045\end{array}$ & .973 & .331 & .058 & .059 & -.059 & .175 \\
\hline
\end{tabular}

\section{Teachers' distress in interacting with parents}

Table 4 shows teachers' difficulties in interacting with parents. The average score for all aspects indicated in the table is above 2.00. This suggests that parents adopt a non-cooperative attitude in cultivating positive relationships with teachers. Teachers write to parents' diaries in student diaries or send notices via electronic mail, but parents do not read or respond to the diary or respond to teachers. Unsupervised parents are unaware of the information sent to parents regarding school plans due to their inability to read school notices sent in emails and other ways. Working mothers do not pay attention to attend scheduled meetings because of your busy schedule. Parents also lack the confidence to communicate with their children's teachers. They hold teachers accountable for the children's performance throughout the school year. One of the main problems teachers face is that parents criticize and confront their children.

The results of the t-tests show a slight difference in relation to all aspects between the groups, as shown in the table in addition to the last one in series 8 . The significant difference between public and private schools is that parents of students in private schools less criticize fewer teachers in the presence of children.

Table 4: School teachers' difficulty in establishing reciprocal relationships with parents $(n=640)$

\begin{tabular}{|c|c|c|c|c|c|c|c|c|c|c|c|c|}
\hline \multirow[t]{2}{*}{$\begin{array}{l}\text { Sr. } \\
\text { no. }\end{array}$} & \multirow[t]{2}{*}{ Content } & \multicolumn{5}{|c|}{ Group Statistics } & \multicolumn{6}{|c|}{ Independent sample t- test $(\mathrm{df}=638)$} \\
\hline & & $\begin{array}{c}\text { School } \\
\text { type }\end{array}$ & M & ean & $\begin{array}{c}\text { Std. } \\
\text { Dev } \\
\text { iation }\end{array}$ & $\begin{array}{l}\text { Std. } \\
\text { Error } \\
\text { Mean }\end{array}$ & $\mathrm{t}$ & $\begin{array}{l}\text { Sig. } \\
(2- \\
\text { tailed) }\end{array}$ & $\begin{array}{c}\text { Mean } \\
\text { Differe } \\
\text { nce }\end{array}$ & $\begin{array}{c}\text { Std. } \\
\text { Emor } \\
\text { Differe } \\
\text { nce } \\
\end{array}$ & $\begin{array}{r}9 \\
\text { Conf } \\
\text { E Interv } \\
\text { Diff } \\
\end{array}$ & $\begin{array}{l}5 \% \\
\text { fidence } \\
\text { fal of the } \\
\text { ference } \\
\end{array}$ \\
\hline 1 & $\begin{array}{l}\text { Non-cooperative } \\
\text { attitude of parents }\end{array}$ & $\begin{array}{l}\text { Public } \\
\text { Private }\end{array}$ & $\begin{array}{l}2.559 \\
2.509\end{array}$ & 2.536 & $\begin{array}{l}.696 \\
.728\end{array}$ & $\begin{array}{l}.038 \\
.042\end{array}$ & .874 & .382 & .049 & .056 & -.061 & .159 \\
\hline \multirow[t]{2}{*}{2} & \multirow{2}{*}{$\begin{array}{l}\text { Parents do not } \\
\text { check their child } \\
\text { diary }\end{array}$} & Public & 2.536 & 2.522 & .743 & .040 & .490 & .624 & .029 & .059 & -.087 & .14 \\
\hline & & Private & 2.507 & & .745 & .043 & & & & & & \\
\hline \multirow[t]{2}{*}{3} & $\begin{array}{l}\text { Uneducated } \\
\text { parents do not } \\
\text { read e mails/ } \\
\text { messages and }\end{array}$ & Public & 2.521 & 2.506 & .731 & .039 & .529 & .597 & .031 & .058 & -.083 & .144 \\
\hline & $\begin{array}{l}\text { remain unaware } \\
\text { of information of } \\
\text { programs related } \\
\text { to school }\end{array}$ & Private & 2.490 & & .732 & .042 & & & & & & \\
\hline \multirow[t]{2}{*}{4} & \multirow{2}{*}{$\begin{array}{l}\text { Working mothers } \\
\text { do not spend } \\
\text { proper time }\end{array}$} & Public & 2.500 & 2.473 & .752 & .041 & .940 & .348 & .056 & .059 & -.061 & .17 \\
\hline & & Private & 2.444 & & .762 & .044 & & & & & & \\
\hline \multirow[t]{2}{*}{5} & $\begin{array}{l}\text { Parents have lack } \\
\text { of confidence to }\end{array}$ & Public & 2.503 & 2.475 & .7196 & .039 & 1.020 & .308 & .059 & .058 & -.055 & .17 \\
\hline & $\begin{array}{l}\text { interact with } \\
\text { teachers }\end{array}$ & Private & 2.444 & & .748 & .043 & & & & & & \\
\hline \multirow[t]{2}{*}{6} & $\begin{array}{l}\text { Often parents } \\
\text { impose total }\end{array}$ & Public & 2.506 & 2.489 & .752 & .041 & .591 & .555 & .036 & .060 & -.083 & .154 \\
\hline & $\begin{array}{l}\text { responsibility of } \\
\text { their child } \\
\text { education to } \\
\text { school }\end{array}$ & Private & 2.470 & & .776 & .045 & & & & & & \\
\hline \multirow[t]{2}{*}{7} & Parents do not & Public & 2.465 & 2.461 & .767 & .041 & .125 & .901 & .007 & .060 & -.111 & .126 \\
\hline & $\begin{array}{l}\text { complaint directly } \\
\text { to the teacher }\end{array}$ & Private & 2.457 & & .758 & .043 & & & & & & \\
\hline \multirow[t]{2}{*}{8} & Criticizing teacher & Public & 2.544 & 2.479 & .689 & .037 & 2.355 & .019 & .137 & .058 & .023 & .25 \\
\hline & $\begin{array}{l}\text { in presence of } \\
\text { children }\end{array}$ & Private & 2.407 & & .784 & .045 & & & & & & \\
\hline
\end{tabular}

IV.

\section{DISCUSSION}

Parent teachers' conversations alleviate parental frustrations regarding children's educational problems and provide parents with opportunities to guide them on effective parenting techniques. The current study investigated the current status of teachers' motives, practices, and problems in relation to parent-teacher interaction. The results suggest that teachers value parent-teacher interaction for a number of reasons. They also work to create reciprocal relationships with parents, adopting a variety of approaches. Send notes, write comments and messages, email through student diaries, organize forums for parent-teacher conferences, and report assessment results through student diaries but face problems to achieve your goal. Parents think their role in education is not important because children's education is the responsibility of the school and the teachers. They criticize teachers in the presence of children and refrain from talking directly to teachers. These illiterate parents are not confident that they will communicate effectively with the teachers, nor can they read the teachers' messages. Working mothers attend fewer meetings because of their professional responsibilities. These issues 
indicate parents' interest and training to participate in their children's educational development. They feel, their responsibility is to send only one child to school. This is a dangerous sign of teachers' quality education and standard work.

In fact, the standard work of teachers does not depend on the availability of $100 \%$ educational resources at the school. It also calls for the attitude of parental cooperation. There is no doubt that quality education is essential in school for quality education, but we cannot ignore the role of parents in training and the accomplishments of one person throughout life.

The main point of this study is that the private sector has a better job than the teachers in the public sector schools. It has demanded the administration of public schools to keep the work serious for them. Generally, parents who are more sensitive to their child's education send their child to a private school. Parents with low resources and poor anxiety about their child's education take less pain and choose public schools for children.

Therefore, public school teachers need to focus on children in school. They need to work about finding opportunities to communicate with their parents and inform them about them. The role of parents in the education of children in school and the importance of parent-teacher interaction.

The results of this study compare with the available literature on the problem that teachers working in elementary schools are not proficient in interacting with parents (Lawrence-Lightfoot, 2004). Although they have knowledge of the art and technique as suggested by education experts (Dorn, 2004 Min Manke \& Anderson, 2003; Kamaro and Machomo, 2015 Ram Ramirez, 2001 Sale Seland, Dohni, Anderson and Gottschak, 2004), but failed to achieve the resulting results because of their lack of motivation, expertise and advanced principles in the school culture.

This requires teacher trainers to think about their teaching methods and teaching materials that enable teachers to gain parental support in the process of learning the teacher. It also advises school administrators to prepare a need-based responsibility chart for teachers. Educate teachers to create a culture in public schools so that parents can work together to achieve their goal of receiving support. The role of the media in the education of parents, the value and the benefits of their connection and the positive role of the school, and especially the positive relationship with their siblings' teachers, can never be overlooked.

\section{Assumptions}

It was assumed that respondents would be representative of diverse parents whose children elementary schools. It was also assumed that teachers who respond to the survey would be representative of classroom teachers employed in elementary schools. It was assumed that parents and teachers would provide honest responses to the survey questions.

Therefore, the top school cadre administration in the country can create a team to design and publish literature to communicate with parents about the importance of parent-teachers in the educational output of elementary-level students.

\section{CONCLUSION}

The findings showed that there were some barriers to children's education. Those cited by the parents include health issues, lack of available care for children, lack of resources at home and school, lack of school transportation, the burden of too much home works, etc. Those cited by the teachers include students' absentees, inability to communicate effectively, not being appreciated by the parents.

The inclusion of open-ended questions in the survey questionnaires helped to find more information as parents and teachers expressed their thoughts without any limitation etc. Several parents wrote brief notes thanking the researcher for reaching out to them and teachers commented that it was the need of the time to discuss such issues at both teachers and parents play a very important role in helping their students /children get quality education by providing a conducive environment in this competitive era. Some teachers said that due to lack of training and capacity building they lack some latest knowledge and skills and they demanded that any policy made for educational betterment should possess the teacher's training as an important part. A majority of parents (whose children study at public schools) said that due to the nonuniform curriculum in the country, their children cannot compete with those who study at elite or private schools. Parents of the children who study at elite and private schools said that they pay huge fees for their children's education and it has become a compulsion for them because they cannot send their children to schools where there is a lack of quality education. They also said that their children might be punished at 
public schools as they have seen it happening in the country.

Both the teachers and parents said that there should be strong coordination between teachers and parents for helping their children perform better at schools. When asked what was the hurdle in making this strong coordination between the two, parents said that they do not get enough time to visit schools and teachers said that they have always welcomed the parents. Teachers of the private schools complained that their schools do not pay them well and they are made to work for longer hours which affects their work-life balance. This ultimately affects their students and their own children's education in one way or the other.

\section{REFERENCES}

[1] Aydin, I., 2006. Ethics in education and teaching. Ankara: PegemAkademi.

[2] Baloglu, N., 2017. School organization and administration. The Turkish education system and school administration. M. M. Arslan (Ed.), Ankara: Soysal. pp: 185-210.

[3] Burns, R.C., 1993. Parent involvement: Promises, problems, and solutions. In. R. C. Burns (Ed.), Parents and schools: From visitors to partners. Washington, D.C: National Education Association. pp: 9-20.

[4] Celenk, S., 2003. The prerequisite for school success: Home-school cooperation. Elementary Education Online, 2(2): 28-34.

[5] Creswell, J.W., 2016. Qualitative inquiry and research design choosing among five approaches. M. Butun \& S. B. Demir (Edt.). Ankara: Siyasal.

[6] Dey, I., 1993. Qualitative data analysis. London: Routledge Taylor \& Francis Group.

[7] Dulger, H., 2015. Expectations of parents, whose children are studies in primary schools, from teachers. Master Thesis, Istanbul Aydin University, Istanbul, Turkey

[8] Ferguson KJ. Facilitating student learning. In: Jeffries WB, Huggett KN, editors. An introduction to medical teaching. New York: Springer; 2010. pp. 1-10.

[9] Kelly PA, Haidet P, Schneider V, Searle N, Seidel CL, Richards BF. A comparison of inclass learner engagement across lecture, problem-based learning, and team learning using the STROBE classroom observation tool. Teach Learn Med. 2005; 17:112-18.

[10] Skinner EA, Belmont MJ. Motivation in the classroom: reciprocal effects of teacher behavior and student engagement across the school year. J Educ Psychol. 1993; 85:57181.

[11] Anderson, L., Krathwohl, D., Airasian, P. et al (2001), A Taxonomy for Learning, Teaching, and Assessing: A revision of Bloom's Taxonomy of Educational Objectives, New York: Pearson, Allyn \& Bacon

[12] Barahal, S. (2008), Thinking about Thinking: Pre- Service Teachers Strengthen their Thinking Artfully, Phi Delta Kappan 90 (4)

[13]Bloom B. S. (1956), Taxonomy of Educational Objectives, Handbook I: The Cognitive Domain, New York: David McKay Co Inc.

[14] Bransford, J., \& Stein, B. (1984), The IDEAL Problem Solver, New York: W. H. Freeman

[15] Brookhart, S. (2010), How to Assess Higher Order Thinking Skills in Your Classroom, ASCD, http://www.ascd.org/Publications/Books/Ov erview/How-to-Assess-Higher-Order-

Thinking-Skills-in-Your-Classroom.aspx

[16] Hattie, J. (2009), Visible Learning: a Synthesis of Over 800 Meta-Analyses Relating to Achievement, Oxon, OX: Routledge

[17]Higgins, S., Hall, E., Baumfield V. \& Moseley D. (2005), A Meta-Analysis of the Impact of the Implementation of Thinking Skills Approaches on Pupils, in Research in Education Library, London: EPPI-Centre, Social Science Research

[18] Kauchak, D., \& Eggen, P. (1998), Learning and Teaching: Research-based Methods (3rd ed.), Boston: Allyn and Bacon

[19] Marso, R., Pigge, F. (1992), A Summary of Published Research: Classroom Teachers' Knowledge and Skills Related to the Development and Use of Teacher-Made Tests, paper presented at the annual conference of the Midwestern Educational Research Association, Chicago, IL 
[20] Marzano, R. (2011), The Art \& Science of Teaching/ The Perils and Promises of Discovery Learning, Educational Leadership, Volume 69, Number 1.

[21]Nitko, A. \& Brookhart, S. (2007), Educational Assessment of Students, Pearson Merrill Prentice Hall

[22] Norris, S. \& Ennis, R. (1989), Evaluating Critical Thinking, Pacific Grove, CA: Midwest Publications

[23] Pogrow, S. (2005), HOTS Revisited: A Thinking Development Approach to Reducing the Learning Gap After Grade 3, Phi Delta Kappan

[24] Slavin, R. (1995), A Model of Effective Instruction, The Educational Forum, 59

[25] Thomas, A., and Thorne, G. (2009), How to Increase Higher Order Thinking, Metarie, LA: Center for Development and Learning, http://www.readingrockets.org/article/34655

[26] Wenglinsky, H. (2004), Closing the Racial Achievement Gap: The Role of Reforming Instructional Practices, Education Policy Analysis Archives, 12 (64).

[27] Airasian, P.W. (1994). Classroom Assessment (2nd Ed.). USA: McGraw-Hill Inc

[28] Airasian, P.W., \& Abrams, L.M. (2003). Classroom Student Evaluation: International Handbook of Educational Evaluation. Netherlands: Kluwer Academic Publishers

[29] Ary, D., Jacobs, L.C., \&Razavieh, A. (2002). Introduction to Research in Education (6th Ed.). Belmont USA: Wadsworth

[30] Beers, B. (2006). Learning-Driven Schools: A Practical Guide for Teachers and Principals. Virginia USA: ASCD, Alexandria

[31]Bloom, B. S. (1976). Human characteristics and school learning. New York: McGraw Hill Bloom's Taxonomy [www.learningandteaching.info/learning/blo omtax.htm Retrieved on 25th Sept 2011

[32]Borg W.R \& Gall M.D (1996) Educational Research (6th ed), White Plains NY Longman Publishers, USA.
[33] Bryman, A. (2008). Social Science Research Methods (3rd Ed.). New York: OUP

[34] Burden, P. R. \& Byrd, D.M. (2010). Methods for Effective Teaching Meeting the Needs of all Students (5th Ed.). Boston, USA: Allyn\& Bacon

[35]Cohen, L., \& Manion, L. (1992). Research Methods in Education (3rd Ed.). London: Routledge

[36] Creswell, J.W (2009). Research Design: Qualitative, Quantitative, and Mixed Methods Approaches (3rd Ed.). Thousand Oaks, California: Sage Publications.

[37]Creswell, J.W., \& Clark, V.P. (2007). Designing and Conducting Mixed Methods Research. California, USA: Sage Publications.

[38] Avvisati, F., Besbas, B. \& Guyon, N. (2010). Parental Involvement in School: A Literature Review. Paris School of Economics. Available:

http://www.parisschoolofeconomics.eu/docs /guyonnina/parentalinvolvement.pdf

[39]Bull, A., Brooking, K. \& Campbell, R. (2008). Successful home-school partnerships.Report prepared for the Ministry of Education by New Zealand Council for Educational Research. Retrieved from http://www.educationcounts.govt.nz/publica tions/schooling/28415/3

[40] Caspe, M. S. (2003). How teachers come to understand families. The School Community Journal, 13(1), 115-131.

[41]Castro, M., Casas, E.,Martin, E., Lizasoain, L., Asencio, E., \& Gaviria, J. (2015). Parental involvement in student academic achievement: A meta-analysis.Educational Research Review, 14, 33-46,

[42]Davern, L. (2004). School-to-home notebooks: What parents have to say? Council for Exceptional Children, 36(5), 2227. 